\title{
Articles
}

Central European Review of Economics \& Finance

Vol. 22, No. 6 (2017), pp. 71-85. D0I: 10.24136/ceref.2017.028

Zbigniew Śleszyński ${ }^{1}$

\section{COUPLE OF THOUGHTS ON THE CONSEQUENCES OF CHANGES IN THE PENSION SYSTEM IN POLAND IN 2017}

The article presents the rules of retirement in selected European countries and the consequences of lowering the retirement age in Poland from October 2017 for the finances, the labor market and pension level. In particular, examples of pension calculations are given with different initial capital levels and different retirement periods. According to the author, it will be necessary to raise the retirement age in the future, but it would require great political courage.

JEL Classification Codes: E24, J260.

Keywords: reduced retirement age, pension level, Social Insurance Fund, minimal pension.

\section{Introduction}

On the $1^{\text {st }}$ of October 2017 the law from 16 $16^{\text {th }}$ November 2016 on the changes in the Law on retirement and other pensions provided by the Social Insurance Fund and some other laws (Journal of Laws 2017, item 38) comes into force in Poland. The most crucial is change in article 24, paragraph 1 of the Law from $17^{\text {th }}$ December 1998 on retirement and other pensions from the Social Insurance Fund (Journal of Laws 1998, No. 162, item 1118), introducing a reduced retirement age. According to the new article insured people born after $31^{\text {st }}$ December 1948 are entitled to retire after reaching a retirement age of at least 60 years for women and at least 65 years for

\footnotetext{
${ }^{1}$ Assistant Professor, Ph.D., K. Pulaski University of Technology and Humanities in Radom, Faculty of Economics and Legal Sciences.
} 
men. It actually means coming back to the previous retirement age, which was gradually increased from $1^{\text {st }}$ January 2013 (Journal of Laws 2012, item 637). This rise was criticized by part of the society (Zieleniecki, 2015), mainly because of lack of sufficient public consultations. It was probably one of the important reasons of losing the elections by PO and PSL in 2015. During the election campaign the opposition accused government of being arrogant and focusing only on economic aspects, but ignoring social consequences (Tkaczuk, 2014).

It is worth noting that reduction of the retirement age was the fulfillment of 2015 election promise given by PIS (currently governing in Poland). Significant influence on the decision to lower the retirement age had NSZZ 'Solidarność', whereas organizations of economists and employers (such as the WiseEurope, Association of Polish Economist) were protesting against the downturn (2016). In turn, A. Sieron (2017), from the Ludwig von Mises Institute of Economics pointed out that reduction in retirement age would negatively affect the labor market, GDP, public finances and pension level (especially for women). The European Commission suggested similar effect, recommending in May 2017 professional activation of women, low-skilled and older people combined with raising the retirement age. Taking into account an additional 330 thousands of retired people at the end of 2017, the government is also wondering how to make the largest part of them remaining in the labor market. All the ideas considered so far to solve this situation are not satisfying. For example, the idea of adding 5 thousand PLN to the retirement account for every extra year of work is completely absurd for people who earn much below the national average, as they will receive minimum pension anyway.

M. Haponiuk (2016) in his analysis notes that:

- Introduced changes completely do not take into account financial situation of Poland, including the condition of Social Insurance Fund from which pensions are paid,

- The change will especially influence woman as their shorter professional experience means less accumulated pension contributions and longer pension period, resulting in lower pensions,

- The number of employees will be reduced and the number of inactive people will increase, thus fewer workers will have to maintain a larger group of retired people,

- The expected effect of reducing the retirement age which weakens the labor market in Poland, will be the growth of the shadow economy, 
- Lowering the retirement age will lead to an increase in the number of people receiving minimal pensions even twice.

Malec and Tyrowicz (2017) also point out the negative effects of lowering the retirement age. The authors emphasize that the lower retirement age means lower retirement pensions, especially among women, which will result in higher fiscal burdens and will also lead to a decrease in national income.

The article attempts to draw attention to selected aspects of lowering the retirement age.

\section{Retirement age in some European countries}

To begin with, Table 1 presents retirement age in different European countries and the changes in it.

Table 1. Retirement age for men and women in chosen European countires

\begin{tabular}{|c|c|c|}
\hline No & State & Retirement age \\
\hline 1 & Austria & $\begin{array}{l}\text { Men: } 65 \text { years, Women: } 60 \text { years. Progressive increase of age limit for women } \\
\text { until the same retirement age as for men will have been reached between the } \\
\text { years } 2024 \text { and } 2033 \text {. }\end{array}$ \\
\hline 2 & Belgium & 65 years. \\
\hline 3 & Bulgaria & $\begin{array}{l}\text { Men: } 64 \text { years of age and } 38 \text { years and } 4 \text { months of insurance; Women: } 61 \text { years } \\
\text { of age and } 35 \text { years and } 4 \text { months of insurance. } \\
\text { From } 1 / 1 / 2017 \text { the retirement age is being increased as follows: } \\
\text { for women: by } 2 \text { months per calendar year until } 31 / 12 / 2029 \text { and by } 3 \text { months from } \\
1 / 1 / 2030 \text { until it reaches } 65 \text {; } \\
\text { for men: by } 2 \text { months per calendar year until } 31 / 12 / 2017 \text { and by } 1 \text { month from } \\
01 / 01 / 2018 \text { until it reaches } 65 \text {. } \\
\text { After } 31 / 12 / 2037 \text { the retirement age will be linked to the life expectancy. } \\
\text { From } 1 / 1 / 2017 \text {, the required period of insurance is being increased by } 2 \text { months } \\
\text { per calendar year until it reaches } 37 \text { years for women and } 40 \text { years for men. }\end{array}$ \\
\hline 4 & Croatia & $\begin{array}{l}\text { Men: } 65 \text { years, Women: } 61 \text { years and } 9 \text { months in } 2017 \\
\text { Men and women long-insured persons with } 41 \text { years of insurance or more: } \\
60 \text { years. } \\
\text { The pensionable age for women is being gradually increased by } 3 \text { months per } \\
\text { calendar year from } 1 \text { November } 2010 \text { onwards, to reach } 65 \text { in } 2030 \text {. } \\
\text { The pensionable age for both women and men will be gradually increased by } \\
3 \text { months per calendar year from } 2031 \text { onwards, to reach } 67 \text { in } 2038 \text {. }\end{array}$ \\
\hline 5 & Cyprus & $\begin{array}{l}65 \text { years for men and women; } 63 \text { years for miners. Pensionable age will be revised } \\
\text { every } 5 \text { years, starting from } 2023 \text { according to the change in life expectancy during } \\
2018-2023 \text {. }\end{array}$ \\
\hline
\end{tabular}


Table 1. Continuation

\begin{tabular}{|c|c|c|}
\hline No & State & Retirement age \\
\hline 6 & Czech Republic & $\begin{array}{l}\text { Men: } 63 \text { years and } 2 \text { months. } \\
\text { Women: depends upon the number of children raised: } \\
\text { no children: } 62 \text { years and } 8 \text { months, } 1 \text { child: } 61 \text { years and } 8 \text { months, } 2 \text { children: } 60 \\
\text { years and } 4 \text { months, } 3 \text { or } 4 \text { children: } 59 \text { years and } 8 \text { months, } 5 \text { or more children: } 58 \\
\text { years and } 8 \text { months. The legal retirement age for men is gradually increasing by } 2 \\
\text { months each year. The legal retirement age for women is increasing by } 4 \text { months } \\
\text { each year ( } 6 \text { months from 2018) until it equals that of men. After that, the increase } \\
\text { will also be } 2 \text { months per year. There is no ceiling on the pensionable age increase. }\end{array}$ \\
\hline 7 & Denmark & $\begin{array}{l}\text { The pensionable age is } 65 \text { in } 2016 \text { and will be gradually increased from } 65 \text { to } 67 \\
\text { in } 2019-22 \text { and to } 68 \text { in } 2030 \text {. The pensionable age is linked to developments in } \\
\text { life-expectancy at age } 60 \text {. It is adjusted every } 5 \text { years (next adjustment will be in } \\
2020 \text { and will be effective } 15 \text { years, i.e. till 2035). Supplementary pension (arbejds- } \\
\text { markedets tillægspension, ATP): } 65 \text { years. }\end{array}$ \\
\hline 8 & Estonia & $\begin{array}{l}\text { Men: } 63 \text { years Women: } 63 \text { years. From } 2017 \text { the gradual increase of the pension- } \\
\text { able age will be continued and pensionable age will be } 65 \text { for men and women by } \\
2026 \text {. }\end{array}$ \\
\hline 9 & Finland & $\begin{array}{l}\text { Statutory earnings-related pension (Työeläke): Old-age pension to one's own } \\
\text { choice between the ages of } 63 \text { to } 68 \text {. In the public sector there are lower individual } \\
\text { retirement ages. National pension (Kansaneläke) and guarantee pension (Taku- } \\
\text { ueläke): } 65 \text { years. }\end{array}$ \\
\hline 10 & France & $\begin{array}{l}\text { General pension scheme for employees (Régime général d'assurance vieillesse } \\
\text { des travailleurs salariés, RGAVTS): if minimum period of affiliation completed: } 60 \\
\text { years for people born before } 1 \text { st of July } 1951 \text {. Increase of } 5 \text { months per year of } \\
\text { birth to reach } 62 \text { years for those born starting from } 1955 \text {. If minimum period of affili- } \\
\text { ation not completed: } 65 \text { years for people born before } 1 \text { st of July } 1951 \text {. Increase of } 5 \\
\text { months per year of birth to reach } 67 \text { years for those born starting from 1955. Sup- } \\
\text { plementary pension schemes for employees (ARRCO) and executives (AGIRC): } \\
\text { Between } 65 \text { and } 67 \text { or upon receipt of the basic pension at a full rate. }\end{array}$ \\
\hline 11 & Greece & 67 years (if 15 years of insurance). 62 years (if 40 years of insurance). \\
\hline 12 & Spain & $\begin{array}{l}65 \text { years (with } 36 \text { years of contributions). } 65 \text { years and four months (with less than } \\
36 \text { years of contributions). Progressive increase until } 2027: 65 \text { years (with } 38 \text { years } \\
\text { and } 6 \text { months of contributions); } 67 \text { years (with less than } 38 \text { years and } 6 \text { months } \\
\text { of contributions). Increase of the legal age (in case of insufficient contributions) of } \\
\text { one month per year until } 2018 \text { and } 2 \text { months per year from then on. }\end{array}$ \\
\hline 13 & The Netherlands & $\begin{array}{l}65 \text { years and three months in } 2015 \text {. As of 2013, the legal retirement age will be } \\
\text { gradually increased to } 66 \text { in } 2018 \text { and } 67 \text { in } 2021 \text {. As of 2022, the legal retirement } \\
\text { age will be linked to life expectancy }\end{array}$ \\
\hline 14 & Ireland & $\begin{array}{l}\text { State pension age for all at } 66 \text { years. State pension age will increase further to } 67 \\
\text { in } 2021 \text { and } 68 \text { in } 2028 .\end{array}$ \\
\hline 15 & Iceland & $\begin{array}{l}\text { National pension (lífeyrir almannatrygginga): } 67 \text { years. Employment pension (lög- } \\
\text { bundnir lífeyrissjóðir): } 65-70 \text { years. }\end{array}$ \\
\hline 16 & Liechtenstein & Women and men: 64 years old. \\
\hline
\end{tabular}


Table 1. Continuation

\begin{tabular}{|c|c|c|}
\hline No & State & Retirement age \\
\hline 17 & Lithuania & $\begin{array}{l}\text { Men: } 63 \text { years and } 4 \text { months. Women: } 61 \text { years and } 8 \text { months. From } 2012 \text { on- } \\
\text { wards, the retirement age increases annually by } 4 \text { months for women and by } 2 \\
\text { months for men until it reaches } 65 \text { for both women and men in } 2026 \text {. }\end{array}$ \\
\hline 18 & Luxembourg & 65 years \\
\hline 19 & Latvia & $\begin{array}{l}62 \text { years and } 9 \text { months. The legal retirement age is gradually increased by } 3 \\
\text { months per year until reaching } 65 \text { years in } 2025 \text {. }\end{array}$ \\
\hline 20 & Malta & $\begin{array}{l}\text { For those born before 1952: Men: 61; Women: 60; Women have the option of retir- } \\
\text { ing at } 61 \text { if they wish. For men and women born: in the years1952 to 1955: 62; in } \\
\text { 1956-1958: 63; in 1959-1962: 64; in } 1962 \text { and subsequent years: } 65 \text {. }\end{array}$ \\
\hline 21 & Germany & $\begin{array}{l}67 \text { years (standard retirement age). The standard retirement age will be gradually } \\
\text { increased to } 67 \text { years from } 2012 \text { to } 2029 \text {, starting with those born in } 1947 \text {. The } \\
\text { first increase amounts to one month per year ( } 65 \text { to } 66 \text { ) and the following to two } \\
\text { months per year ( } 66 \text { to } 67) \text {. For all those born after 1963, the standard retirement } \\
\text { age of } 67 \text { years shall apply. }\end{array}$ \\
\hline 22 & Norway & $\begin{array}{l}\text { The retirement age is flexible between } 62 \text { and } 75 \text {. In order to draw an old-age pen- } \\
\text { sion before reaching the age of } 67 \text {, special provisions apply, i.e. the person must } \\
\text { be entitled to at least the minimum pension for persons with an insurance period of } \\
40 \text { years, when they reach } 67 \text {. }\end{array}$ \\
\hline 23 & Poland & From October 201765 years for men and 60 for women. \\
\hline 24 & Portugal & $\begin{array}{l}66 \text { years and } 2 \text { months for men and women in } 2016 \text { (after } 2015 \text {, the normal age for } \\
\text { access to a pension varies depending on the average life expectancy at the age of } \\
65.65 \text { years for beneficiaries legally prevented from working beyond that age (e.g., } \\
\text { pilots, drivers of heavy vehicles). When the beneficiary reaches the age of } 65 \text {, the } \\
\text { normal pensionable age is reduced by four months for each calendar year after the } \\
\text { contribution period of } 40 \text { years, with a } 65 \text {-year threshold. }\end{array}$ \\
\hline 25 & Romania & $\begin{array}{l}\text { Men: } 65 \text { years. Women: } 60 \text { years and } 4 \text { months on } 1 \text { July } 2016 \text {, gradually increas- } \\
\text { ing to } 63 \text { years by } 1 \text { January } 2030 \text {. }\end{array}$ \\
\hline 26 & Slovakia & $\begin{array}{l}62 \text { years for all population groups (except for women with multiple children, for } \\
\text { whom this retirement age will be reached in 2023). From } 2017 \text { onwards the legal } \\
\text { retirement age will gradually increase depending on the increase in average life } \\
\text { expectancy in the reference age (common for both men and women). }\end{array}$ \\
\hline 27 & Slovenia & 65 years. \\
\hline 28 & Switzerland & Men: 65 years Women: 64 year. \\
\hline 29 & Sweden & $\begin{array}{l}\text { Flexible retirement age from } 61 \text { for earnings-related pensions and from } 65 \text { years } \\
\text { for Guaranteed pension. }\end{array}$ \\
\hline 30 & Hungary & $\begin{array}{l}\text { Retirement age is increased by } 6 \text { months for each age cohort, from } 62 \text { for those } \\
\text { born before } 1952 \text { to } 65 \text { for those born in } 1957 \text { and after (i.e. for those born in 1952, } \\
\text { it is } 62 \text { plus } 6 \text { months, for those born in 1953, } 63 \text { and so on). }\end{array}$ \\
\hline
\end{tabular}


Table 1. Continuation

\begin{tabular}{|c|c|c|}
\hline No & State & Retirement age \\
\hline 31 & Great Britain & $\begin{array}{l}\text { Men: } 65 \text { years Women: } 60 \text { years (up until } 5 \text { April 2010). From } 6 \text { April } 2010 \text { women's } \\
\text { State Pension age is gradually rising until it reaches age } 65 \text { in November } 2018 \text {. } \\
\text { From December } 2018 \text { the State Pension age for both men and women will start } \\
\text { to increase to reach } 66 \text { by October } 2020 \text {. The government is planning further in- } \\
\text { creases, which will raise the state pension age from } 66 \text { to } 67 \text { between } 2026 \text { and } \\
\text { 2028. They will then review it every five years in line with life expectancy. }\end{array}$ \\
\hline 32 & Italy & $\begin{array}{l}\text { Male employees of the private sector, self-employed and para-subordinate work- } \\
\text { ers: } 66 \text { years and } 7 \text { months; Male and female civil servants: } 66 \text { years and } 7 \\
\text { months; Female employees of the private sector: } 65 \text { years and } 7 \text { months; Female } \\
\text { self-employed and para-subordinate workers: } 66 \text { years and } 1 \text { month (see Annex } \\
\text { on the social protection of the self-employed). The retirement age is being gradu- } \\
\text { ally increased according to the increase in life expectancy. As of January } 2021 \text {, the } \\
\text { retirement age cannot be lower than } 67 \text { (it will reach } 69 \text { and } 9 \text { months by the year } \\
\text { 2050). The pension payment deferment scheme no longer applies except for cer- } \\
\text { tain duly certified categories of hard jobs to which the previous "Quota system" still } \\
\text { applies. Such categories include: miners, workers engaged in asbestos removal, } \\
\text { night-shift workers, public transport heavy-vehicles' drivers, etc. }\end{array}$ \\
\hline
\end{tabular}

Source: own work based on MISSOC, data from 2016 r., (http://www.missoc.org/INFORMATIONBASE/informationBase.jsp. Retrieved May 28, 2017).

Information presented in Table 1 shows that practically Poland has the lowest retirement age among European countries and there is no algorithm for its gradual increase after withdrawing reform from early 2013. The retirement age of women was significantly decreased, while in Europe the general trend is to make the retirement age of women and men equal. It is worth noting that European Commission suggests that retirement age in European Union should be gradually raised to 70 years of age.

\section{Lowering retirement age and Burden on workers}

Decreasing retirement age in Poland may be surprising, especially if we compare it with data from recent years on average life length and the indicator of economic burden - the ratio of number of pre-working (0-17) and post-working $(60 / 65+)$ people to the number of people in production age (18-59 / 64). Table 2 contains the numbers: 
Table 2. Indicator of economic Burden and average life length in Poland

\begin{tabular}{|l|c|c|c|c|c|c|c|c|}
\hline \multicolumn{1}{|c|}{ Year } & 2000 & 2010 & 2011 & 2012 & 2013 & 2014 & 2015 & 2016 \\
\hline $\begin{array}{l}\text { Indicator of economic burden in } \\
\text { percent }\end{array}$ & 64 & 55 & 56 & 57 & 58 & 59 & 60 & 62 \\
\hline $\begin{array}{l}\text { Average length of life - men and } \\
\text { women together in years }\end{array}$ & 73.7 & 76.2 & 76.5 & 76.7 & 77.0 & 77.6 & 77.6 & 77.9 \\
\hline
\end{tabular}

Source: http://stat.gov.pl/wskazniki-makroekonomiczne/. Retrieved July 23, 2017.

The data presented in Table 2 show that in the last few years, on the one hand, the economic burden was rising steadily (in 2016 there were 6.2 people in non-production age for every 10 people in production age) and on the other hand, the average life length is steadily increasing. Taking into account the fact that Polish pension system is participative - in the long term it must lead to increased tax burden on the working population. Even more pessimistic are forecasts until year 2060 published by the Social Insurance Institution (ZUS), which are presented in Table 3.

Table 3. Population of Poland forecasts - data after lowering retirement age

\begin{tabular}{|l|c|c|c|c|c|c|}
\hline \multicolumn{1}{|c|}{ Year } & 2015 & 2020 & 2030 & 2040 & 2050 & 2060 \\
\hline Total population (in thousands): & 38490 & 38346 & 37403 & 36108 & 34696 & 33126 \\
\hline In this: & 6959 & 6954 & 6223 & 5561 & 5499 & 5230 \\
\hline In pre-production age & 24020 & 22818 & 21569 & 19976 & 17427 & 16029 \\
\hline In production age & 7511 & 8573 & 9610 & 10570 & 11769 & 11867 \\
\hline In post-production age & 60.2 & 68.0 & 73.4 & 80.8 & 99.1 & 106.7 \\
\hline Indicator of economic burden in percent
\end{tabular}

Source: Forecast of receipts and expenses... (2016): p. 13.

Table 3 presents the forecasts of Polish population by economic category by 2060 . Practically in 2050 year there will be one unemployed per worker. At the same time, it doesn't seem that 500+ program significantly changed the proportions. Some action is needed to radically change the situation, as it can lead to break down of public finances. If the increase in retirement age was not reversed, the data would look as in Table 4. 
Table 4. Population of Poland forecasts- data before lowering retirement age

\begin{tabular}{|l|c|c|c|c|c|c|}
\hline \multicolumn{1}{|c|}{ Year } & 2015 & 2020 & 2030 & 2040 & 2050 & 2060 \\
\hline Total population (in thousands): & 38490 & 38346 & 37403 & 36108 & 34696 & 33126 \\
\hline In this: & 6959 & 6954 & 6223 & 5561 & 5499 & 5230 \\
\hline In pre-production age & 24414 & 23843 & 22926 & 22385 & 19834 & 17759 \\
\hline In production age & 7117 & 7584 & 8253 & 8162 & 9362 & 10137 \\
\hline In post-production age & 57.7 & 61.0 & 63.1 & 61.3 & 74.9 & 86.5 \\
\hline Indicator of economic burden in percent
\end{tabular}

Source: Forecast of receipts and expenses... (2016): p. 13.

According to data in Table 4 at least till 2040 the situation seems to be stable. Unfortunately, fulfillment of some electoral promises, although gives some short-term benefits to the government, in the long term might kill the economy and the working people. It will be necessary in the coming years to raise the retirement age again, but it will be a very difficult political decision and at the moment there is no party that could do it.

\section{Financial implications of lowering retirement age}

The financial implication of lowering retirement age is mainly additional expense of around 55 billion PLN between 2017 and 2021, as shown in Table 5, plus an additional 714 thousands retirees.

Table 5. Model 1: Panel OLS estimation using 126 observations 16 cross-sectional data units are included. Time series length: minimum 7, maximum 8 . The dependent variable (Y): PKB $B_{\text {it }}$

\begin{tabular}{|l|r|c|c|c|c|c|}
\hline \multicolumn{1}{|c|}{ Year } & \multicolumn{1}{c|}{2017} & \multicolumn{1}{c|}{2018} & \multicolumn{1}{c|}{2019} & \multicolumn{1}{c|}{$\mathbf{2 0 2 0}$} & \multicolumn{1}{c|}{2021} & \multicolumn{1}{c|}{ Suma } \\
\hline $\begin{array}{l}\text { Revenue } \\
\text { (in thousand PLN) }\end{array}$ & 1377800 & 985500 & -640100 & -1707200 & -2715200 & -2699200 \\
\hline $\begin{array}{l}\text { Costs (in thousand } \\
\text { PLN) }\end{array}$ & 2182400 & 10448000 & 11798200 & 13457200 & 14313300 & 52199100 \\
\hline Total (in thousand PLN) & -804600 & -9462500 & -12438400 & -15164000 & -17028500 & -54898000 \\
\hline $\begin{array}{l}\text { Additional potential } \\
\text { retirees (in thousands of } \\
\text { people) }\end{array}$ & 330 & 148 & 90 & 92 & 54 & 714 \\
\hline
\end{tabular}

Source: ZUS data 
It is possible that forecasts presented in Table 5 are somewhat too pessimistic, especially on the side of revenue. It might be higher due to increased employment of foreigners and positive migration rate.

Lowering retirement age will worsen the balance of Social Insurance Fund, as illustrated by the next two tables. Table 6 is based on forecasts for a higher retirement age, and Table 7 illustrates forecasts after the retirement age was lowered in October 2017. Those two tables include three scenarios: basic, pessimistic and optimistic.

Table 6. Social Insurance Fund balance in 3 variants of forecasts of receipts and expenditures for years 2017-2021

\begin{tabular}{|c|c|c|c|c|c|}
\hline Specification & 2017 & 2018 & 2019 & 2020 & 2021 \\
\hline \multicolumn{6}{|l|}{ Variant number 1 (basic) } \\
\hline Balance in billion PLN & -56.5 & -58.5 & -61.5 & -64 & -68.5 \\
\hline Balance in \% GDP & $-2.82 \%$ & $-2.75 \%$ & $-2.71 \%$ & $-2.67 \%$ & $-2.68 \%$ \\
\hline \multicolumn{6}{|c|}{ Variant number 2 (pessimistic) } \\
\hline Balance in billion PLN & -65 & -71 & -78 & -83 & -90.5 \\
\hline Balance in \% GDP & $-3.32 \%$ & $-3.44 \%$ & $-3.56 \%$ & $-3.67 \%$ & $-3.84 \%$ \\
\hline \multicolumn{6}{|c|}{ Variant number 3 (optimistic) } \\
\hline Balance in billion PLN & -50 & -50 & -49 & -49 & -50.5 \\
\hline Balance in \% GDP & $-2.48 \%$ & $-2.30 \%$ & $-2.10 \%$ & $-1.95 \%$ & $-1.89 \%$ \\
\hline
\end{tabular}

Source: Forecast of receipts and expenses... (2015): pp. 19-30.

Table 7. Social Insurance Fund balance in 3 variants of forecasts of receipts and expenditures for years 2018-2022

\begin{tabular}{|c|c|c|c|c|c|}
\hline Specification & 2018 & 2019 & 2020 & 2021 & 2022 \\
\hline \multicolumn{6}{|l|}{ Variant number 1 (basic) } \\
\hline Balance in billion PLN & -56.5 & -60 & -63.5 & -68.5 & -73.5 \\
\hline Balance in \% GDP & $-2.72 \%$ & $-2.72 \%$ & $-2.71 \%$ & $-2.75 \%$ & $-2.77 \%$ \\
\hline \multicolumn{6}{|c|}{ Variant number 2 (pessimistic) } \\
\hline Balance in billion PLN & -65 & -72 & -79.5 & -88.5 & -96.5 \\
\hline Balance in \% GDP & $-3.22 \%$ & $-3.39 \%$ & $-3.56 \%$ & $-3.76 \%$ & $-3.93 \%$ \\
\hline \multicolumn{6}{|c|}{ Variant number 3 (optimistic) } \\
\hline Balance in billion PLN & -48.5 & -49.5 & -51 & -53 & -55.5 \\
\hline Balance in \% GDP & $-2.28 \%$ & $-2.17 \%$ & $-2.08 \%$ & $-2.03 \%$ & $-1.98 \%$ \\
\hline
\end{tabular}

Source: Forecast of receipts and expenses... (2015): pp. 16-27. 
It seems that the most likely scenario is the basic one, but it should be noted that it assumes ambitious indicators (eg annual real GDP growth of 3.6-3.9\% and unemployment at the end of 2022 at $6 \%$ ). In a short term, the situation presented in both tables are not significantly different, but in all variants the deficit of the Social Insurance Fund is significantly increasing in 2022. We can suppose that situation will deteriorate in the following years.

\section{Impact of lowering retirement age on level of pension}

According to GUS data - in 2015 year 1.357 million people employed in the national economy received gross wages not higher than the minimum wage (1750 PLN), which was about $13 \%$ of the total number of employed people (similarly as in previous years). We should assume that this number will not change significantly in subsequent years. If we assume that the minimum wage worker will work for 35 years (from 26 to 60 years), receiving a minimum wage of 2000 PLN (year 2017) and not taking into account the change in the value of money over time, we can calculate that when retiring he will have fund of PLN 163,968, giving pension PLN 643 - so the minimum one. If such a person retires at the age of 67 - calculated number slightly exceeds the amount of the minimum pension (PLN 1000). It means that the recipients of the minimum wage should retire as early as possible, since the transition time will not affect the amount of benefits received. Therefore, people who receive the lowest wages will not lose on lowering their retirement age. Their retirement benefits, despite early retirement, will not change. The vast majority will therefore use this opportunity which might also rise the temptation to continue work in the shadow economy. This is the result of a jump increase in the minimum pension in March 2017 to PLN 1000. Ratio between the lowest pension and the minimum and average wage in the years 2002-2017 is illustrated in Table 8, which shows a sharp improvement in the ratios in 2017.

The age of retirement will affect pension level if the worker salary exceeds about 1.5 minimum wage in the period of employment (in 2017 3000 PLN). In such case each additional year of work means an increase in pension level by about $8 \%$. Approximate level of future pension, depending on the retirement age, the amount of revalued initial capital and updated contributions to the Social Insurance Fund at the end of 2017, and annual contribution in various variants is presented in Table 9. For the calculations, it was assumed that future annual revaluation index is equal to $3 \%$. It was also assumed that employee will have 60 years on June 1, 2018. 
Table 8. Ratio between the lowest pension to minimum and average wage during 2002-2017 in Poland

\begin{tabular}{|c|c|c|c|c|c|c|}
\hline Year & $\begin{array}{c}\text { The lowest } \\
\text { pension }\end{array}$ & $\begin{array}{c}\text { Minimum } \\
\text { wage }\end{array}$ & $\begin{array}{c}\text { Ratio between } \\
\text { the lowest } \\
\text { pension and } \\
\text { minimum } \\
\text { wage }\end{array}$ & $\begin{array}{c}\text { Average } \\
\text { wage }\end{array}$ & $\begin{array}{c}\text { Ratio between } \\
\text { the lowest } \\
\text { pension and } \\
\text { average wage }\end{array}$ & $\begin{array}{c}\text { Ratio between } \\
\text { minimum and } \\
\text { average wage }\end{array}$ \\
\hline 2002 & 532.91 & 760 & $70.12 \%$ & 2133.71 & $24.98 \%$ & $35.62 \%$ \\
\hline 2003 & 552.63 & 800 & $69.08 \%$ & 2201.47 & $25.10 \%$ & $36.34 \%$ \\
\hline 2004 & 562.58 & 824 & $68.27 \%$ & 2289.57 & $24.57 \%$ & $35.99 \%$ \\
\hline 2005 & 562.58 & 849 & $66.26 \%$ & 2380.29 & $23.63 \%$ & $35.67 \%$ \\
\hline 2006 & 597.46 & 899.1 & $66.45 \%$ & 2477.23 & $24.12 \%$ & $36.29 \%$ \\
\hline 2007 & 597.46 & 936 & $63.83 \%$ & 2691.03 & $22.20 \%$ & $34.78 \%$ \\
\hline 2008 & 636.29 & 1126 & $56.51 \%$ & 2943.88 & $21.61 \%$ & $38.25 \%$ \\
\hline 2009 & 675.10 & 1276 & $52.91 \%$ & 3102.96 & $21.76 \%$ & $41.12 \%$ \\
\hline 2010 & 706.29 & 1317 & $53.63 \%$ & 3224.94 & $21.90 \%$ & $40.84 \%$ \\
\hline 2011 & 728.18 & 1386 & $52.54 \%$ & 3399.52 & $21.42 \%$ & $40.77 \%$ \\
\hline 2012 & 799.18 & 1500 & $53.28 \%$ & 3521.67 & $22.69 \%$ & $42.59 \%$ \\
\hline 2013 & 831.15 & 1600 & $51.95 \%$ & 3650.06 & $22.77 \%$ & $43.83 \%$ \\
\hline 2014 & 844.45 & 1680 & $50.26 \%$ & 3783.43 & $22.32 \%$ & $44.40 \%$ \\
\hline 2015 & 880.45 & 1750 & $50.31 \%$ & 3899.78 & $22.58 \%$ & $44.87 \%$ \\
\hline 2016 & 882.56 & 1850 & $47.71 \%$ & 4060,00 & $21.67 \%$ & $45.57 \%$ \\
\hline 2017 & 1000.00 & 2000 & $50.00 \%$ & 4263,00 & $23.52 \%$ & $46.92 \%$ \\
\hline
\end{tabular}

Source: Review of the pension system, Information of the Council of Ministers for the Polish Parliament about the effects of the Law from 11 May 2012 on the changes in Law on pensions from the Social Insurance Fund (Journal of Laws, No. 637), together with proposals for amendments. P. 78, Warsaw 2017.

It should be emphasized that these are approximate calculations, assuming for example the life expectancies published by GUS on March 24, 2017. Those indicators will be changed in 2018 (like each year). The annual premium contribution of PLN 4685 corresponds to the minimum wage, whereas PLN 6000 is the effect of monthly wage of PLN 2 560, similarly the contribution of PLN 9000 is the wage PLN 3840, the contribution of PLN 12000 - the wage PLN 5123 and contribution PLN 15000 - the wage PLN 6404. 
Table 9. Approximate level of future pension, depending on the retirement age, the amount of revalued initial capital and contributions to the Social Insurance Fund

\begin{tabular}{|c|c|c|c|c|c|c|c|c|c|c|c|c|}
\hline \multicolumn{2}{|c|}{ Retirement age } & 60 & 61 & 62 & 63 & 64 & 65 & 66 & 67 & 68 & 69 & 70 \\
\hline \multicolumn{2}{|c|}{ Life expectancies } & 255 & 246.1 & 237.3 & 228.8 & 220.3 & 212 & 203.7 & 195.6 & 187.6 & 179.6 & 171.8 \\
\hline $\begin{array}{l}\text { Revalued } \\
\text { initial } \\
\text { capital and } \\
\text { updated } \\
\text { contribu- } \\
\text { tions (on } 31 \\
\text { XII 2017) }\end{array}$ & $\begin{array}{r}\text { annual } \\
\text { contri- } \\
\text { bution } \\
\text { (in PLN) }\end{array}$ & \multicolumn{11}{|c|}{ Pension level (in PLN) } \\
\hline \multirow[t]{4}{*}{$283253 \mathrm{zł}$} & 4685.0 & 1118.5 & 1212.5 & 1314.6 & 1424.6 & 1545.0 & 1675.4 & 1818.7 & 1974.5 & 2145.1 & 2333.7 & 2539.7 \\
\hline & 9000.0 & 1125.5 & 1237.3 & 1359.1 & 1490.8 & 1635.1 & 1792.0 & 1964.6 & 2152.7 & 2359.3 & 2587.8 & 2838.1 \\
\hline & 12000.0 & 1130.4 & 1254.6 & 1390.1 & 1536.8 & 1697.7 & 1873.0 & 2066.0 & 2276.7 & 2508.1 & 2764.4 & 3045.6 \\
\hline & 15000.0 & 1135.3 & 1271.8 & 1421.0 & 1582.7 & 1760.4 & 1954.0 & 2167.4 & 2400.6 & 2657.0 & 2941.1 & 3253.1 \\
\hline \multirow[t]{4}{*}{$450000 \mathrm{zł}$} & 6000.0 & 1774.5 & 1917.9 & 2073.7 & 2241.1 & 2424.3 & 2622.8 & 2840.6 & 3077.3 & 3336.4 & 3622.5 & 3935.1 \\
\hline & 9000.0 & 1779.4 & 1935.2 & 2104.6 & 2287.1 & 2487.0 & 2703.8 & 2942.0 & 3201.2 & 3485.2 & 3799.2 & 4142.5 \\
\hline & 12000.0 & 1784.3 & 1952.5 & 2135.5 & 2333.1 & 2549.6 & 2784.8 & 3043.4 & 3325.1 & 3634.1 & 3975.8 & 4350.0 \\
\hline & 15000.0 & 1789.2 & 1969.7 & 2166.5 & 2379.1 & 2612.3 & 2865.9 & 3144.8 & 3449.0 & 3783.0 & 4152.5 & 4557.5 \\
\hline \multirow[t]{4}{*}{$500000 \mathrm{zł}$} & 6000.0 & 1970.6 & 2127.2 & 2297.2 & 2479.9 & 2679.8 & 2896.2 & 3133.7 & 3391.7 & 3674.0 & 3985.8 & 4326.2 \\
\hline & 9000.0 & 1975.5 & 2144.5 & 2328.2 & 2525.9 & 2742.4 & 2977.2 & 3235.1 & 3515.6 & 3822.8 & 4162.4 & 4533.7 \\
\hline & 12000.0 & 1980.4 & 2161.7 & 2359.1 & 2571.9 & 2805.1 & 3058.2 & 3336.5 & 3639.5 & 3971.7 & 4339.1 & 4741.1 \\
\hline & 15000.0 & 1985.3 & 2179.0 & 2390.0 & 2617.9 & 2867.7 & 3139.3 & 3437.9 & 3763.4 & 4120.6 & 4515.7 & 4948.6 \\
\hline \multirow[t]{4}{*}{$550000 \mathrm{zł}$} & 6000.0 & 2166.7 & 2336.4 & 2520.8 & 2718.7 & 2935.2 & 3169.6 & 3426.8 & 3706.1 & 4011.6 & 4349.0 & 4717.3 \\
\hline & 9000.0 & 2171.6 & 2353.7 & 2551.7 & 2764.7 & 2997.9 & 3250.6 & 3528.2 & 3830.0 & 4160.5 & 4525.7 & 4924.8 \\
\hline & 12000.0 & 2176.5 & 2371.0 & 2582.6 & 2810.7 & 3060.5 & 3331.7 & 3629.6 & 3953.9 & 4309.3 & 4702.3 & 5132.3 \\
\hline & 15000.0 & 2181.4 & 2388.3 & 2613.5 & 2856.7 & 3123.2 & 3412.7 & 3731.0 & 4077.8 & 4458.2 & 4879.0 & 5339.7 \\
\hline \multirow[t]{4}{*}{$600000 \mathrm{zł}$} & 6000.0 & 2362.7 & 2545.7 & 2744.3 & 2957.5 & 3190.7 & 3443.0 & 3719.9 & 4020.4 & 4349.2 & 4712.2 & 5108.5 \\
\hline & 9000.0 & 2367.6 & 2563.0 & 2775.2 & 3003.5 & 3253.3 & 3524.0 & 3821.3 & 4144.4 & 4498.1 & 4888.9 & 5315.9 \\
\hline & 12000.0 & 2372.5 & 2580.3 & 2806.2 & 3049.5 & 3316.0 & 3605.1 & 3922.7 & 4268.3 & 4647.0 & 5065.6 & 5523.4 \\
\hline & 15000.0 & 2377.5 & 2597.5 & 2837.1 & 3095.5 & 3378.6 & 3686.1 & 4024.1 & 4392.2 & 4795.8 & 5242.2 & 5730.8 \\
\hline \multirow[t]{4}{*}{$650000 \mathrm{zł}$} & 6000.0 & 2558.8 & 2755.0 & 2967.8 & 3196.3 & 3446.1 & 3716.4 & 4013.0 & 4334.8 & 4686.9 & 5075.5 & 5499.6 \\
\hline & 9000.0 & 2563.7 & 2772.2 & 2998.8 & 3242.3 & 3508.8 & 3797.5 & 4114.4 & 4458.7 & 4835.7 & 5252.1 & 5707.0 \\
\hline & 12000.0 & 2568.6 & 2789.5 & 3029.7 & 3288.3 & 3571.4 & 3878.5 & 4215.8 & 4582.7 & 4984.6 & 5428.8 & 5914.5 \\
\hline & 15000.0 & 2573.5 & 2806.8 & 3060.6 & 3334.3 & 3634.1 & 3959.5 & 4317.2 & 4706.6 & 5133.5 & 5605.5 & 6122.0 \\
\hline \multirow[t]{4}{*}{$700000 \mathrm{zł}$} & 6000.0 & 2754.9 & 2964.2 & 3191.4 & 3435.1 & 3701.6 & 3989.8 & 4306.1 & 4649.2 & 5024.5 & 5438.7 & 5890.7 \\
\hline & 9000.0 & 2759.8 & 2981.5 & 3222.3 & 3481.1 & 3764.2 & 4070.9 & 4407.5 & 4773.1 & 5173.3 & 5615.4 & 6098.2 \\
\hline & 12000.0 & 2764.7 & 2998.8 & 3253.2 & 3527.1 & 3826.9 & 4151.9 & 4508.9 & 4897.0 & 5322.2 & 5792.0 & 6305.6 \\
\hline & 15000.0 & 2769.6 & 3016.1 & 3284.2 & 3573.1 & 3889.5 & 4232.9 & 4610.3 & 5021.0 & 5471.1 & 5968.7 & 6513.1 \\
\hline
\end{tabular}

Source: Own computations. 
Z. Śleszyński, Couple of thoughts on the consequences...

Table 10. Percent growth in the pension level while retiring in specific age comparing to the age of 60

\begin{tabular}{|c|c|c|c|c|c|c|c|c|c|c|c|c|}
\hline \multicolumn{2}{|c|}{ Retirement age } & 60 & 61 & 62 & 63 & 64 & 65 & 66 & 67 & 68 & 69 & 70 \\
\hline $\begin{array}{l}\text { Revalued } \\
\text { initial } \\
\text { capital (in } \\
\text { PLN) }\end{array}$ & $\begin{array}{c}\text { Yearly } \\
\text { contribu- } \\
\text { tion }\end{array}$ & $\begin{array}{l}\text { Pen- } \\
\text { sion } \\
\text { level }\end{array}$ & \multicolumn{10}{|c|}{$\begin{array}{l}\text { Percent growth in the pension level while retiring in specific age } \\
\text { comparing to the age of } 60\end{array}$} \\
\hline \multirow[t]{4}{*}{283253} & 4685 & 1118.5 & 8.4 & 17.5 & 27.4 & 38.1 & 49.8 & 62.6 & 76.5 & 91.8 & 108.6 & 127.1 \\
\hline & 9000 & 1125.5 & 9.9 & 20.8 & 32.5 & 45.3 & 59.2 & 74.6 & 91.3 & 109.6 & 129.9 & 152.2 \\
\hline & 12000 & 1130.4 & 11.0 & 23.0 & 36.0 & 50.2 & 65.7 & 82.8 & 101.4 & 121.9 & 144.6 & 169.4 \\
\hline & 15000 & 1135.3 & 12.0 & 25.2 & 39.4 & 55.1 & 72.1 & 90.9 & 111.5 & 134.0 & 159.1 & 186.5 \\
\hline \multirow[t]{4}{*}{450000} & 6000 & 1774.5 & 8.1 & 16.9 & 26.3 & 36.6 & 47.8 & 60.1 & 73.4 & 88.0 & 104.1 & 121.8 \\
\hline & 9000 & 1779.4 & 8.8 & 18.3 & 28.5 & 39.8 & 52.0 & 65.3 & 79.9 & 95.9 & 113.5 & 132.8 \\
\hline & 12000 & 1784.3 & 9.4 & 19.7 & 30.8 & 42.9 & 56.1 & 70.6 & 86.4 & 103.7 & 122.8 & 143.8 \\
\hline & 15000 & 1789.2 & 10.1 & 21.1 & 33.0 & 46.0 & 60.2 & 75.8 & 92.8 & 111.4 & 132.1 & 154.7 \\
\hline \multirow[t]{4}{*}{500000} & 6000 & 1970.6 & 7.9 & 16.6 & 25.8 & 36.0 & 47.0 & 59.0 & 72.1 & 86.4 & 102.3 & 119.5 \\
\hline & 9000 & 1975.5 & 8.6 & 17.9 & 27.9 & 38.8 & 50.7 & 63.8 & 78.0 & 93.5 & 110.7 & 129.5 \\
\hline & 12000 & 1980.4 & 9.2 & 19.1 & 29.9 & 41.6 & 54.4 & 68.5 & 83.8 & 100.6 & 119.1 & 139.4 \\
\hline & 15000 & 1985.3 & 9.8 & 20.4 & 31.9 & 44.4 & 58.1 & 73.2 & 89.6 & 107.6 & 127.5 & 149.3 \\
\hline \multirow[t]{4}{*}{550000} & 6000 & 2166.7 & 7.8 & 16.3 & 25.5 & 35.5 & 46.3 & 58.2 & 71.0 & 85.1 & 100.7 & 117.7 \\
\hline & 9000 & 2171.6 & 8.4 & 17.5 & 27.3 & 38.1 & 49.7 & 62.5 & 76.4 & 91.6 & 108.4 & 126.8 \\
\hline & 12000 & 2176.5 & 8.9 & 18.7 & 29.1 & 40.6 & 53.1 & 66.8 & 81.7 & 98.0 & 116.0 & 135.8 \\
\hline & 15000 & 2181.4 & 9.5 & 19.8 & 31.0 & 43.2 & 56.4 & 71.0 & 86.9 & 104.4 & 123.7 & 144.8 \\
\hline \multirow[t]{4}{*}{600000} & 6000 & 2362.7 & 7.7 & 16.2 & 25.2 & 35.0 & 45.7 & 57.4 & 70.2 & 84.1 & 99.4 & 116.2 \\
\hline & 9000 & 2367.6 & 8.3 & 17.2 & 26.9 & 37.4 & 48.8 & 61.4 & 75.0 & 90.0 & 106.5 & 124.5 \\
\hline & 12000 & 2372.5 & 8.8 & 18.3 & 28.5 & 39.8 & 52.0 & 65.3 & 79.9 & 95.9 & 113.5 & 132.8 \\
\hline & 15000 & 2377.5 & 9.3 & 19.3 & 30.2 & 42.1 & 55.0 & 69.3 & 84.7 & 101.7 & 120.5 & 141.0 \\
\hline \multirow[t]{4}{*}{650000} & 6000 & 2558.8 & 7.7 & 16.0 & 24.9 & 34.7 & 45.2 & 56.8 & 69.4 & 83.2 & 98.4 & 114.9 \\
\hline & 9000 & 2563.7 & 8.1 & 17.0 & 26.5 & 36.9 & 48.1 & 60.5 & 73.9 & 88.6 & 104.9 & 122.6 \\
\hline & 12000 & 2568.6 & 8.6 & 18.0 & 28.0 & 39.0 & 51.0 & 64.1 & 78.4 & 94.1 & 111.4 & 130.3 \\
\hline & 15000 & 2573.5 & 9.1 & 18.9 & 29.6 & 41.2 & 53.9 & 67.8 & 82.9 & 99.5 & 117.8 & 137.9 \\
\hline \multirow[t]{4}{*}{700000} & 6000 & 2754.9 & 7.6 & 15.8 & 24.7 & 34.4 & 44.8 & 56.3 & 68.8 & 82.4 & 97.4 & 113.8 \\
\hline & 9000 & 2759.8 & 8.0 & 16.8 & 26.1 & 36.4 & 47.5 & 59.7 & 73.0 & 87.5 & 103.5 & 121.0 \\
\hline & 12000 & 2764.7 & 8.5 & 17.7 & 27.6 & 38.4 & 50.2 & 63.1 & 77.1 & 92.5 & 109.5 & 128.1 \\
\hline & 15000 & 2769.6 & 8.9 & 18.6 & 29.0 & 40.4 & 52.8 & 66.5 & 81.3 & 97.5 & 115.5 & 135.2 \\
\hline
\end{tabular}

Source: Own computations based on table 9.

Based on calculation from table 10 it is clear that decision to retire at the age of 65 instead of 60 results in an increase in the pension level for more than $50 \%$. If we retire at the age of 67 (instead of 60), the average pension will increase by more than $75 \%$. From this point of view, the employee should decide at the latest retirement, it especially refer to women. Let's notice that 
their pensions will be very low and will range between 18 and $45 \%$ of the last wage. It means that retiring at the minimum age would lead to very low pension.

\section{Conclusions}

Analyzing the data presented in the article, both about the level of future pensions and the situation of the Polish Security Fund it is hard to see any positive effect of lowering the retirement age, except the benefit for the least earners - they will not lose on the early retirement because they would still receive a minimum pension. It is therefore hard to disagree with M. Szczepanski's conclusions (2016): ,It seems that in the longer term it will be necessary to extend the retirement age, because of demographics and economic calculations, which in social policy will sooner or later pave the way.". The retirement benefits for miners, uniformed services should be reduced, while the opposite trend is observed. It was recently expanded to customs officers and border guards. It is worth noting that the political situation in upcoming years (including upcoming local and parliamentary elections) will definitely not be help in resolving this issue. Attempts to block future changes in the retirement age, by for example resolving this issue in a referendum without necessary educational action, should be treated as irresponsible and calculated only for immediate political purposes. About the probable need of future increase of the retirement age mentions even ZUS in the White Paper (2016). It is however hard today to pinpoint any party that could decide to do this, no matter on the political costs.

\section{References}

Baza danych MISSOC, (http://www.missoc.org/INFORMATIONBASE/informationBase.jsp. Retrieved May 28, 2017.

Biała Księga (2016), ZUS, Warszawa.

http://stat.gov.pl/wskazniki-makroekonomiczne/, Retrieved July 23, 2017,

Komunikat Prezesa GUS z dnia 24 marca 2017 r. w sprawie tablicy średniego dalszego trwania życia kobiet i mężczyzn,(M.P 2017 r. poz. 292).

Haponiuk M., Dłuższa czy krótsza praca, Instytut Obywatelski, Warszawa, Analiza 13/2016. 
Malec M., Tyrowicz J (2017), Niski wiek emerytalny, wysoka cena, pp. 29-34, [in:] Starzenie się ludności, rynek pracy i finanse publiczne w Polsce, http://ibs. org.pl/publications/starzenie-sie-ludnosci-rynek-pracy-i-finanse-publiczne-wpolsce/. Retrieved June 11, 2017.

Obniżenie wieku emerytalnego ocena skutków regulacji (OSR) wprowadzenia w życie prezydenckiego projektu ustawy, WISEEUROPA i Towarzystwo Ekonomistów Polskich, 14 XI 2016.

Prognoza wpływów i wydatków Funduszu Ubezpieczeń Społecznych na lata 2016-2020, (2014), ZUS, Warszawa,

Prognoza wpływów i wydatków Funduszu Ubezpieczeń Społecznych na lata 2017-2021, (2015), ZUS, Warszawa.

Prognoza wpływów i wydatków funduszu emerytalnego do 2060 roku, (2016), ZUS, Warszawa.

Prognoza wpływów i wydatków Funduszu Ubezpieczeń Społecznych na lata 2018-2022, (2017), ZUS, Warszawa.

Sieroń A., Biedni sześćdziesięcioletni - skutki obniżenia wieku emerytalnego, Instytut Misesa, listopad 2016,

Szczepański M. (2016). Analiza i ocena proponowanych zmian ustawowego wieku emerytalnego w Polsce. Finanse, Rynki Finansowe, Ubezpieczenia, 1(79), pp.739-751; www.wneiz.pl/frfu

Tkaczuk M., Podnoszenie wieku emerytalnego a problemy polskiej polityki społecznej, Studia Ekonomiczne, Uniwersytet Ekonomiczny w Katowicach, 2014, nr 179, pp. 96-205.

Ustawa z dnia 17 grudnia 1998 r. o emeryturach i rentach z Funduszu Ubezpieczeń Społecznych (Dz.U. 1998 nr 162 poz. 1118).

Ustawa z dnia 16 listopada 2016 r. o zmianie ustawy o emeryturach i rentach z Funduszu Ubezpieczeń Społecznych oraz niektórych innych ustaw, (Dz.U. 2017 poz. 38).

Ustawa z dnia 11 maja 2012 r. o zmianie ustawy o emeryturach i rentach z Funduszu Ubezpieczeń Społecznych oraz niektórych innych ustaw, (Dz.U. 2012 poz. 637).

Zieleniecki M., Kilka refleksji na temat podwyższenia wieku emerytalnego w Polsce, (na marginesie wyroku Trybunału Konstytucyjnego w sprawie K 43/120), Gdańskie Studia Prawnicze, tom XXXIII, Gdańsk, 2015. 